\title{
One year of hepatitis B immunoglobulin plus tenofovir therapy is safe and effective in preventing recurrent hepatitis B infection post-liver transplantation
}

\author{
Tomohiro Tanaka MD ${ }^{1,2}$, Eberhard L Renner MD ${ }^{1}$, Nazia Selzner MD PhD¹, \\ George Therapondos $\mathrm{MD}^{1}$, Leslie B Lilly $\mathrm{MD}^{1}$
}

T Tanaka, EL Renner, N Selzner, G Therapondos, LB Lilly. One year of hepatitis B immunoglobulin plus tenofovir therapy is safe and effective in preventing recurrent hepatitis $B$ infection postliver transplantation. Can J Gastroenterol Hepatol 2014;28(1): 41-44.

BACKGROUND: Hepatitis B immunoglobulin (HBIG) given in combination with a nucleos $(\mathrm{t})$ ide analogue has reduced the rate of recurrent hepatitis B virus (HBV) infection following liver transplantation (LT); however, the most effective protocol remains unclear.

OBJECTIVE: To evaluate the use of tenofovir disoproxil fumarate (TDF) in combination with one year of low-dose HBIG.

METHODS: Twenty-four adults who underwent LT for HBV-related liver disease at the University Health Network (Toronto, Ontario) and received TDF ( \pm lamivudine) and one year of HBIG to prevent recurrent HBV infection from June 2005 to June 2011 were evaluated.

RESULTS: The median length of follow-up post-LT was 29.1 months. Three patients died during the follow-up period. Patient survival was $100 \%$ and $84.1 \%$ at one and five years, respectively. None of the patients developed recurrent HBV infection. No significant adverse event was observed due to TDF administration; renal function preand post-LT were also acceptably preserved.

CONCLUSION: The present study demonstrated that a short, finite course of low-dose HBIG combined with maintenance of long-term TDF staring before LT is cost-effective and safe. However, further prospective study involving a larger patient cohort with a longer followup period is required to confirm the results.

Key Words: HBIG; Hepatitis B; Liver transplantation; Tenofovir
Une thérapie d'immunoglobuline de l'hépatite B pendant un an et de ténofovir est sécuritaire et efficace pour prévenir une récurrence de l'infection par l'hépatite $B$ après une transplantation hépatique

HISTORIQUE : L'immunoglobuline de l'hépatite B (IgHB) administrée en association avec un analogue du nucléos(t)ide réduit le taux de récurrence de l'infection par le virus de l'hépatite $\mathrm{B}(\mathrm{VHB})$ après une transplantation hépatique, mais on ne sait pas quel protocole est le plus efficace.

OBJECTIF : Évaluer l'utilisation du fumarate de ténofovir disproxil (FTD) associé à une faible dose d'IgHB pendant un an.

MÉTHODOLOGIE : Les chercheurs ont évalué 24 patients qui avaient subi une TH en raison d'une maladie hépatique liée au VHB au Réseau universitaire de santé de Toronto, en Ontario, et qui ont reçu du FTD ( \pm lamivudine) et de l'IgHB pendant un an pour prévenir une récurrence de l'infection par le VHB entre juin 2005 et juin 2011.

RÉSULTATS : La durée médiane du suivi après la TH était de 29, 1 mois. Trois patients sont décédés pendant le suivi. La survie des patients s'élevait à $100 \%$ au bout d'un an et à $84,1 \%$ au bout de cinq ans. Aucun des patients n'a présenté de récurrence de l'infection par le VHB. Les chercheurs n'ont observé aucun événement indésirable d'importance en raison de l'administration de FTD, et la préservation de la fonction rénale était acceptable avant et après la $\mathrm{TH}$.

CONCLUSION : La présente étude a démontré qu'un traitement court et circonscrit dans le temps constitué d'une faible dose d'IgHB associée au maintien à long terme du FTD amorcé avant la TH est rentable et sécuritaire. Cependant, il faudra mener une autre étude prospective auprès d'une cohorte de patients plus vaste pendant une période de suivi plus longue pour confirmer les résultats.

risk of resistance, which may result in progression to decompensated liver cirrhosis $(9,10)$. A recent study (11) demonstrated the safety and efficacy of TDF for patients with decompensated liver cirrhosis, although information regarding TDF administration in LT settings remains scarce.

We conducted the current study to evaluate the efficacy and safety of TDF in combination with one-year of low-dose HBIG as prophylaxis for recurrent $\mathrm{HBV}$ infection post-LT.

HBIG (6), its limited availability in some regions or countries, and inconvenient mode of administration have limited the broad use of combination regimens. The potential risk of transmitted infections with the use of HBIG cannot be overlooked. In an attempt to minimize the use of HBIG, we recently published a study describing the feasibility of a short, finite course of HBIG of 12 months, mainly in combination with long-term use of LAM (7).

However, the long-term use of LAM has been reported to introduce high rates of resistance to the drug in both LT and non-LT settings due to mutations or amino acid substitutions in the conserved tyr-met-aspasp (YMDD) motif (8). With its potent antiviral activity and barrier to the development of resistance, tenofovir disoproxil fumarate (TDF) has been recognized as one of the first drugs to suppress HBV without the

\section{METHODS}

Patients and antiviral prophylaxis protocol

A prospectively maintained institutional database of transplant patients (Organ Transplant Tracking Record [OTTR], HKS Medical Information Systems, USA), an internal transplantation database linked to the electronic medical record of all patients evaluated for a solid organ transplant at the University Health Network, Toronto, Ontario) was used to identify all adults ( $\geq 18$ years of age) who received low-dose HBIG for one year combined with maintenance TDF (or LAM plus TDF) to prevent recurrent HBV infection post-LT for HBV-related

\footnotetext{
${ }^{1}$ Multi-Organ Transplant Program, Liver Transplant Unit, University Health Network, University of Toronto, Toronto, Ontario; ${ }^{2}$ Organ Transplantation Service, The University of Tokyo Hospital, Tokyo, Japan

Correspondence: Dr Leslie B Lilly, University Health Network, Multi-Organ Transplant Program, 585 University Avenue, NCSB-11-1241, Toronto,

Ontario M5G 2N2. Telephone 416-790-9717, fax 416-340-3511, e-mail dr.les.lilly@uhn.ca

Received for publication July 6, 2013. Accepted August 11, 2013
} 


\section{TABLE 1}

\section{Patient characteristics}

\begin{tabular}{lr}
\hline Age, years, median (range) & $54(23-65)$ \\
Male sex & $22(92)$ \\
Ethnicity & $12(50)$ \\
Asian & $8(33)$ \\
Caucasian & $4(17)$ \\
Others & \\
Indication & $7(29)$ \\
Chronic liver failure & $3(13)$ \\
Acute on chronic liver failure & $14(58)$ \\
Hepatocellular carcinoma & $8(33)$ \\
HBeAg pretransplantation (+) & $12(50)$ \\
HBV DNA pretransplantation $<2.1_{\text {log }}$ copies $/ m L$ & $4(17)$ \\
Living donor liver transplantation & $8(33)$ \\
Use of induction therapy* & $7(29)$ \\
Post-transplant prednisone withdrawal time $>4$ months & \\
\hline
\end{tabular}

Data presented as $n$ (\%) unless otherwise indicated. *Three with thymoglobulin and five with basiliximab. HBeAg Hepatitis $B$ e antigen; HBV Hepatitis $B$ virus

end-stage liver disease from May 2005 to June 2011, with follow-up through June 2012 or death. Patients who were started on TDF to treat recurrent $\mathrm{HBV}$ infection post-LT were not included. Patient data were collected retrospectively via the OTTR database. The primary end point of the present study was overall survival; the secondary end point was the recurrence rates of HBV infection following LT, defined as the appearance of positive hepatitis B surface antigen ( $\mathrm{HBsAg}$ ) and detectable serum HBV DNA post-LT.

\section{HBV prophylaxis regimen}

Since 1999, all patients undergoing LT for HBV-related end-stage liver disease have been protocolized to continue the nucleos(t)ide analogue (NA) on which they were pretransplant, or to introduce the NA (LAM until 2007, and entecavir [ETV] or TDF since 2008) immediately postLT for patients who were not on any NAs pre-LT, along with one year of HBIG: first dose of HBIG (2000 IU) given intravenously during the anhepatic phase, followed by a daily dose for seven days (intravenously, then intramuscularly), then weekly three times, then monthly 11 times (7). The dose of TDF was based on guideline recommendations from the American Association for the Study of Liver Diseases (9).

\section{Immunosuppression}

Maintenance immunosuppression consisted of a double- or triple-drug regimen that included tacrolimus, cyclosporine or rapamycin, and prednisone, with or without mycophenolate mofetil. Prednisone was generally planned to be withdrawn within the first four months (it was withdrawn in almost all patients within 12 months of LT). Tacrolimus and rapamycin were monitored according to trough levels, and cyclosporine according to blood concentration level at $2 \mathrm{~h}$ postdose $(\mathrm{C} 2)$. Some patients received induction therapy, including basiliximab, thymoglobulin or rabbit antithymocyte globulin, generally for renalor neurological-sparing purposes, primarily to delay the introduction of calcineurin inhibitors (7).

\section{HBV evaluation}

Regarding HBV evaluation pre-LT, viral markers, including HBsAg, hepatitis B surface antibody ( $\mathrm{HBs} \mathrm{Ab})$, hepatitis B e antigen ( $\mathrm{HBeAg})$, hepatitis $\mathrm{B}$ e antibody $(\mathrm{HBe} A b)$ and hepatitis $\mathrm{B}$ core antibody, were measured using standard commercial assays (Abbott Laboratories, USA). HBV DNA levels were was measured using real-time polymerase chain reaction (Cobas TaqMan, Roche Molecular Systems, USA). Following LT, HBV DNA and HBsAg levels were measured every three months for the first year, and then every six months thereafter. In contrast to earlier studies, the titres of $\mathrm{HBs} A b$ were not measured; hence, HBIG dosing was not adjusted.

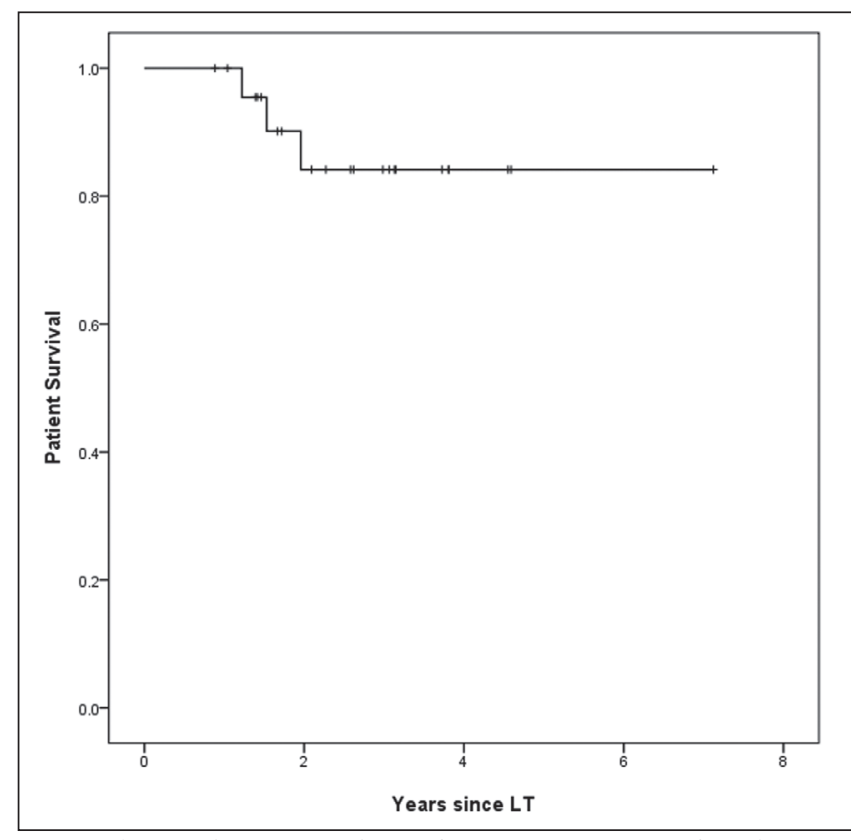

Figure 1) Cumulative survival rate of patients receiving tenofovir disoproxil fumarate ( \pm lamivudine) in combination with one year of hepatitis $B$ immunoglobulin $(n=24)$ to prevent recurrent hepatitis B post-liver transplantation (LT)

\section{Statistical analysis}

SPSS version 17.0 (IBM Corporation, USA) was used to analyze the relevant data. Continuous variables are summarized as mean $\pm \mathrm{SD}$, or median and range, whereas categorical variables are presented as proportions. The Student's $t$ test, Fisher's exact test or ANOVA were used for group comparisons as appropriate. Overall survival was calculated using the Kaplan-Meier method; $\mathrm{P}<0.05$ was considered to be statistically significant.

\section{RESULTS}

Twenty-four patients received one year of HBIG in combination with TDF-based NA as a prophylaxis for recurrent HBV infection: 15 with TDF and nine with LAM + TDF were identified. In the nine patients who received LAM + TDF in combination with HBIG, TDF had been added to LAM for breakthrough hepatitis before LT. None of the 24 patients were coinfected with hepatitis $C$ virus, hepatitis D virus or HIV. The median post-LT follow-up period was 29.1 months (range 12.5 to 85.5 months). Of the 24 patients, 16 (67\%) had hepatocellular carcinoma (HCC), of whom five $(31 \%)$ were beyond the Milan criteria at LT. During the follow-up period, three patients (two within Milan criteria and one beyond Milan criteria) developed recurrent HCC. Other clinical demographic data regarding the 24 patients in the present study are summarized in Table 1 .

\section{Overall survival}

Three patients died during the follow-up period: two with recurrent HCC (14.7 and 18.4 months post-LT) and one with chronic rejection (23.5 months post-LT). None of the deceased patients experienced recurrent HBV infection. Overall patient survival calculated by Kaplan-Meier analysis was $100 \%$ and $84.1 \%$ at one and five years postLT, respectively (Figure 1).

\section{$\mathrm{HBV}$ recurrence}

None of the 24 patients developed recurrent HBV infection in the median follow-up period of 29.1 months. Neither HBsAg nor HBV DNA levels became detectable during the follow-up period.

Safety of prophylaxis with TDF plus one year of HBIG No adverse events were observed in the study group due to TDF administration. Regarding renal function, the median serum creatinine level and 
TABLE 2

Renal function parameters at liver transplantation (LT), one-year post-LT and final follow-up

\begin{tabular}{lcccc}
\hline & At LT & One-year follow-up & Final follow-up & P \\
\hline Serum creatinine, $\mu \mathrm{mol} / \mathrm{L}$ & $85.3 \pm 32.3$ & $96.9 \pm 23.8$ & $96.0 \pm 26.9$ & 0.26 \\
eCCr, $\mathrm{mL} / \mathrm{min}^{*}$ & $85.5 \pm 22.6$ & $73.9 \pm 23.5$ & $73.7 \pm 22.0$ & 0.09 \\
\hline
\end{tabular}

Data presented as mean $\pm S D$ unless otherwise indicated. *Estimated creatinine clearance (eCCr) using the Modification of Diet in Renal Disease equation

estimated creatinine clearance (CCr) by Modification of Diet in Renal Disease (MDRD) equation at LT were $85.3 \mu \mathrm{mol} / \mathrm{L}$ and $85.5 \mathrm{~mL} / \mathrm{min}$, respectively. There were no statistically significant changes in serum creatinine level or estimated CCr by MDRD equation during the follow-up period (Table 2).

\section{DISCUSSION}

In the current study, LT recipients who underwent the prophylaxis regimen consisting of indefinite TDF in combination with low-dose HBIG for one year showed a five-year survival rate of approximately $85 \%$. None of the 24 patients developed recurrent HBV infection with the prophylaxis regimen during the median follow-up period of 29.1 months. No significant adverse events related to TDF were observed. In addition, no patients experienced significantly impaired renal function.

The administration of HBIG and NA, especially when used in combination, has drastically reduced the post-LT HBV recurrence rate (5). However, the optimal timing to discontinue HBIG and choice of NA remain uncertain. There have been several reports citing the safety of an HBIG-free regimen (12-14). We previously reported the feasibility of finite use of HBIG post-LT for HBV-related disease; however, the rate of recurrent HBV infection was suboptimal (approximately $8.6 \%$ at five years post-LT), probably because LAM was predominantly used in the study group (7). We concluded in the report that one year of HBIG would be more acceptable when used with a more potent NA, such as TDF, which has been well recognized as one of the first choices to treat hepatitis $B(9,10)$.

To date, several published studies have described the efficacy and safety of TDF in LT recipients (15-19). However, two included a relatively small number of patients $(n=3$ [15] and $n=4$ [16]). Stravitz et al (17) reported that the combination of TDF and emtricitabine was successfully switched from HBIG plus NA (ETV, LAM and/or adefovir) in 21 patients, although 14\% of them developed detectable $\mathrm{HBsAg}$ levels after conversion to the drug. Similarly, Cholongitas et al (18) reported that 15 patients who received TDF as a substitute to the regimen of non-TDF NA plus HBIG did not experience clinical manifestations of recurrent HBV infection, although one-third of the patients were coinfected with hepatitis $D$ virus, which has been reported to reduce the risk of recurrent hepatitis B (20). Importantly, the prospective phase 2 randomized study published by Teperman et al (19) in 2013 compared recipients of TDF + emtricitabine in combination with indefinite HBIG $(n=19)$ and those with TDF + emtricitabine with HBIG for 24 weeks only $(n=18)$, as prophylaxis for HBV recurrence. They reported that none of the randomized groups experienced HBV recurrence during the follow-up period of 72 weeks. All of these studies concluded that the safety of administrating TDF in this setting was well preserved. In the current study, TDF was continued before LT in combination with a short course of low-dose HBIG postLT. In addition to the reduced cost and risk of transmitted infection from cessation of HBIG at one year post-LT, this regimen has satisfactorily suppressed HBV in these 24 patients, with no HBV recurrence during the median follow-up period of 29.1 months.

The potential renal toxicity of TDF remains a significant concern, especially in patients with decompensated liver disease and post-LT. In the current study cohort, the estimated CCr by MDRD was acceptable (mean $85.5 \mathrm{~mL} / \mathrm{min}$ ). In addition, even after LT, renal function did not change significantly up to the latest follow up, although the estimated CCr by MDRD appeared to trend downward, likely due to the administration of calcineurin inhibitors post-LT.
The present retrospective study had several limitations. The size of the study population was small and the follow-up period was relatively short. In addition, our regimen still contains HBIG, which could be safely avoided when newer NAs, such as ETV (12) or TDF, were administered. Another study is strongly warranted to confirm the efficacy and safety of TDF monotherapy as prophylaxis for recurrent HBV infection.

\section{CONCLUSION}

Our study demonstrated the satisfactory efficacy and safety of a regimen consisting of one year of HBIG and TDF ( \pm LAM) to prevent recurrent $\mathrm{HBV}$ infection post-LT for HBV-related liver disease. The general discontinuation of HBIG, especially when newer, potent NAs (TDF in the present study) are administered, showed acceptable overall survival and HBV recurrence rate in our patient cohort, although larger prospective study with a longer follow-up period should be conducted to confirm the result. In addition, the great challenge not to initiate $\mathrm{HBIG}$ but to maintain newer potent NAs, such as TDF or ETV alone, should be tested in future studies.

DISCLOSURES: This study was not funded. This manuscript was not prepared nor funded in any part by a commercial organization. None of the authors have any conflict of interest to declare with regard to the content of this article.

ACKNOWLEDGEMENT: The authors are grateful to Drs Sandra Fischer, Maha Guindi and Oyedele Adeyi for their contribution to the histological examination of the liver biopsies.

\section{REFERENCES}

1. Todo S, Demetris AJ, Van Thiel D, Teperman L, Fung JJ, Starzl TE. Orthotopic liver transplantation for patients with hepatitis B virus-related liver disease. Hepatology 1991;13:619-26.

2. Rosenau J, Bahr MJ, Tillmann HL, et al. Lamivudine and low-dose hepatitis B immune globulin for prophylaxis of hepatitis B reinfection after liver transplantation possible role of mutations in the YMDD motif prior to transplantation as a risk factor for reinfection. J Hepatol 2001;34:895-902.

3. Markowitz JS, Martin P, Conrad AJ, et al. Prophylaxis against hepatitis $\mathrm{B}$ recurrence following liver transplantation using combination lamivudine and hepatitis B immune globulin. Hepatology 1998;28:585-9.

4. Dumortier J, Chevallier P, Scoazec JY, Berger F, Boillot O. Combined lamivudine and hepatitis B immunoglobulin for the prevention of hepatitis B recurrence after liver transplantation: Long-term results. Am J Transplant 2003;3:999-1002.

5. Cholongitas E, Goulis J, Akriviadis E, Papatheodoridis GV. Hepatitis B immunoglobulin and/or nucleos(t)ide analogues for prophylaxis against hepatitis $\mathrm{B}$ virus recurrence after liver transplantation: A systematic review. Liver Transpl 2011;17:1176-90.

6. Dan YY, Wai CT, Yeoh KG, Lim SG. Prophylactic strategies for hepatitis B patients undergoing liver transplant: A cost-effectiveness analysis. Liver Transpl 2006;12:736-46.

7. Tanaka T, Benmousa A, Marquez M, Therapondos G, Renner EL, Lilly LB. The long-term efficacy of nucleos $(\mathrm{t})$ ide analog plus a year of low-dose HBIG to prevent HBV recurrence post-liver transplantation. Clin Transplant 2012;26:E561-9.

8. Crespo G, Marino Z, Navasa M, Forns X. Viral hepatitis in liver transplantation. Gastroenterology 2012;142:1373-83 e1.

9. Lok AS, McMahon BJ. Chronic hepatitis B: Update 2009. Hepatology 2009;50:661-2.

10. EASL Clinical Practice Guidelines: Management of chronic hepatitis B. J Hepatol 2009;50:227-42. 
11. Liaw YF, Sheen IS, Lee CM, et al. Tenofovir disoproxil fumarate (TDF), emtricitabine/TDF, and entecavir in patients with decompensated chronic hepatitis B liver disease. Hepatology 2011;53:62-72.

12. Fung J, Cheung C, Chan SC, et al. Entecavir monotherapy is effective in suppressing hepatitis B virus after liver transplantation. Gastroenterology 2011;141:1212-9.

13. Gane EJ, Patterson S, Strasser SI, McCaughan GW, Angus PW. Combination of lamivudine and adefovir without hepatitis B immune globulin is safe and effective prophylaxis against hepatitis B virus recurrence in hepatitis $B$ surface antigen-positive liver transplant candidates. Liver Transpl 2013;19:268-74.

14. Fung J, Chan SC, Cheung C, et al. Oral nucleoside/nucleotide analogs without hepatitis B immune globulin after liver transplantation for hepatitis B. Am J Gastroenterol 2013;108:942-8.

15. Jimenez-Perez M, Saez-Gomez AB, Mongil Poce L, Lozano-Rey JM, de la Cruz-Lombardo J, Rodrigo-Lopez JM. Efficacy and safety of entecavir and/or tenofovir for prophylaxis and treatment of hepatitis B recurrence post-liver transplant. Transplant Proc 2010;42:3167-8.
16. Daude M, Rostaing L, Saune K, et al. Tenofovir therapy in hepatitis B virus-positive solid-organ transplant recipients. Transplantation 2011;91:916-20.

17. Stravitz RT, Shiffman ML, Kimmel M, et al. Substitution of tenofovir/emtricitabine for hepatitis B immune globulin prevents recurrence of hepatitis B after liver transplantation. Liver Int 2012;32:1138-45.

18. Cholongitas E, Vasiliadis T, Antoniadis N, Goulis I, Papanikolaou V, Akriviadis E. Hepatitis B prophylaxis post liver transplantation with newer nucleos $(\mathrm{t})$ ide analogues after hepatitis $\mathrm{B}$ immunoglobulin discontinuation. Transpl Infect Dis 2012;14:479-87.

19. Teperman LW, Poordad F, Bzowej N, et al. Randomized trial of emtricitabine/tenofovir disoproxil fumarate after hepatitis B immunoglobulin withdrawal after liver transplantation. Liver Transpl 2013;19:594-601.

20. Roche B, Samuel D. Liver transplantation in delta virus infection. Semin Liver Dis 2012;32:245-55. 


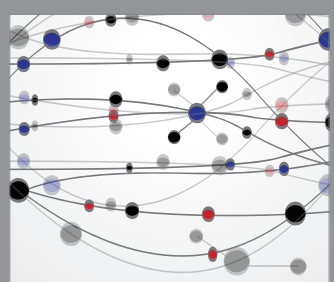

The Scientific World Journal
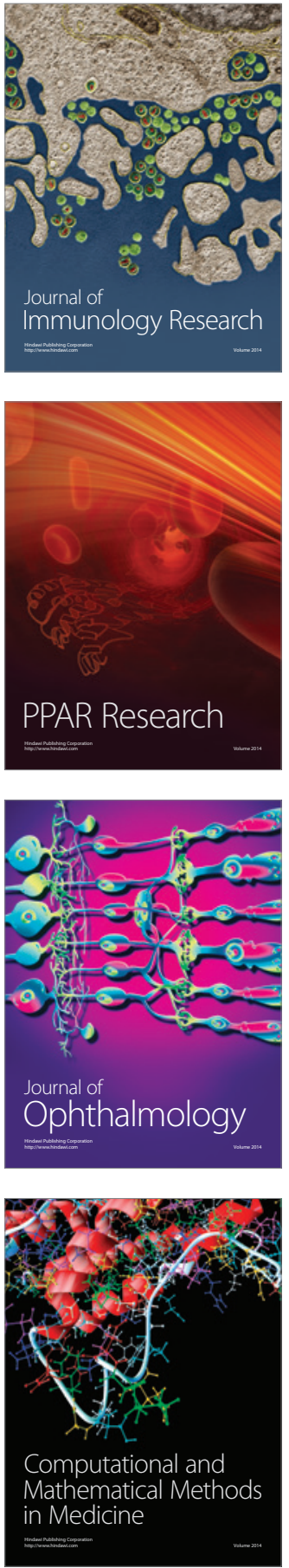

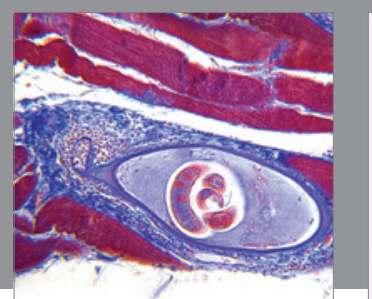

Gastroenterology Research and Practice

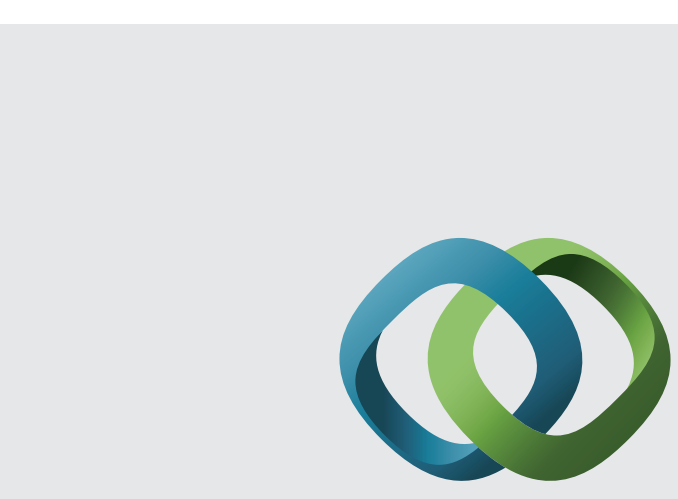

\section{Hindawi}

Submit your manuscripts at

http://www.hindawi.com
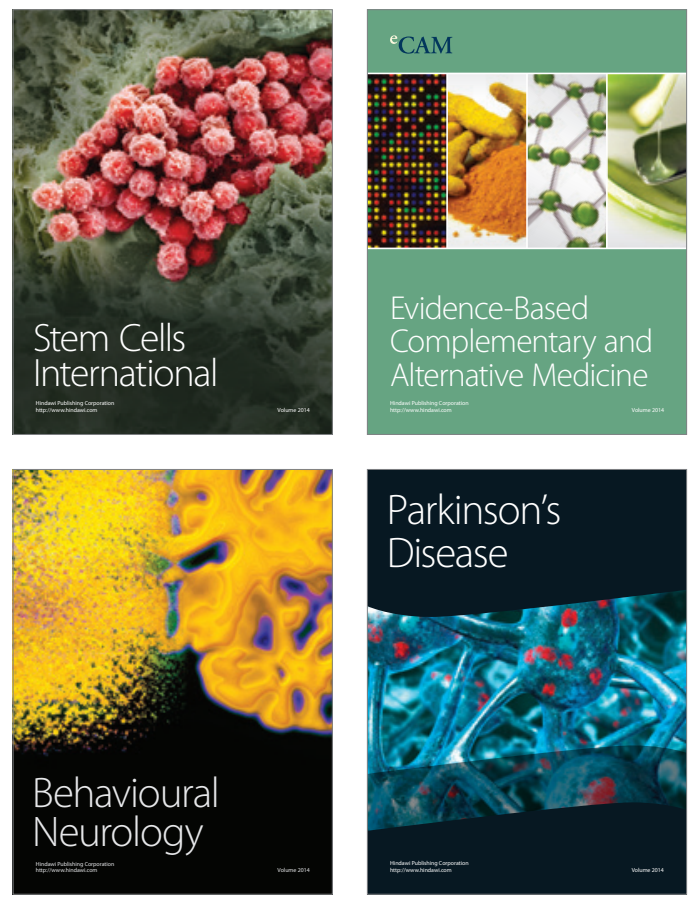
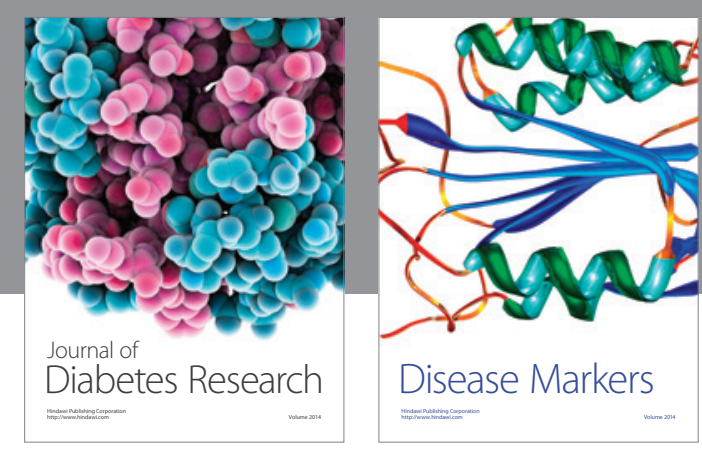

Disease Markers
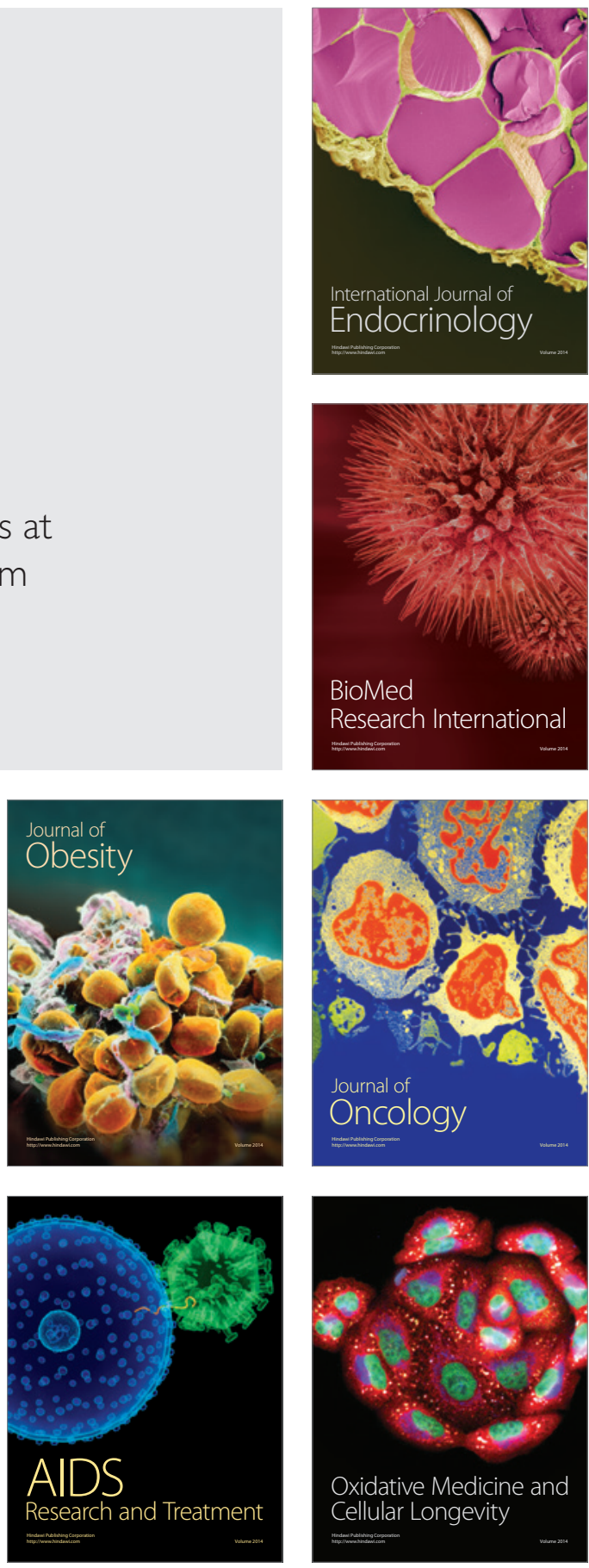